\title{
Maniçoba for sheep and goats - forage yield, conservation strategies, animal performance and quality of products
}

\section{Maria Letícia Rodrigues Gomes ${ }^{1}$ (i) Fabiana Castro Alves ${ }^{1}$ (D) José Renaldo Vilar da Silva Filho ${ }^{* *}$ (D) Clesio Morgado de Souza ${ }^{2}(\mathbb{0})$ Maria Naiara Pereira da Silva ${ }^{1}(\mathbb{0})$ Roberto Araújo Santana Junior ${ }^{1}(\mathbb{B}$ Luara Coelho de $\operatorname{Souza}^{3}(\mathbb{D})$ Tadeu Vinhas Voltolini ${ }^{4}(\mathbb{D}$}

${ }^{1}$ Centro de Ciências Agrárias, Universidade Federal do Vale do São Francisco (UNIVASF), 56304-917, Petrolina, PE, Brasil. E-mail: renaldovilar.zootecnia@gmail.com.*Corresponding author.

${ }^{2}$ Instituto Federal de Educação, Ciência e Tecnologia do Sertão Pernambucano (IFSertãoPE), Santa Maria da Boa Vista, PE, Brasil. ${ }^{3}$ Universidade de Pernambuco (UPE), Petrolina, PE, Brasil.

${ }^{4}$ Empresa Brasileira de Pesquisa Agropecuária (Embrapa Semiárido), Petrolina, PE, Brasil.

ABSTRACT: In dry regions worldwide, providing feed for ruminants has been a great challenge, with a need to use plants which contribute to the resilience of production systems. Maniçoba is seen as a potential forage resource in the Brazilian semiarid, being used as hay or silage to feed ruminants. This review summarized results regarding forage production of maniçoba, in addition to dry matter (DM) intake, productive performance, and quality of animal products obtained providing maniçoba based diets, when compared to diets composed by other roughages

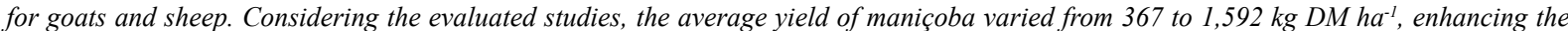
forage yield by increasing plant fertilization and planting density. Diets based on maniçoba promoted similar or higher intake of DM and productive performance for goats and sheep, when compared to diets comprising other forage resources. The quality of animal products was also similar to the ones obtained with diets based on traditional roughages, such as Tifton 85 hay or spineless cactus. Therefore, maniçoba allows a forage production that may contribute to ruminant production systems in semiarid environment and promote productive performance and animal product quality compatible to the ones provided by traditional forage plants.

Key words: forage alternative, forage resource, wild cassava, Manihot, cyanogenic plant.

Maniçoba para ovinos e caprinos: produção de forragem, estratégias de conservação, desempenho do animal e qualidade dos produtos

RESUMO: Nas regiões secas mundiais, fornecer alimentos para ruminantes tem sido um grande desafio, havendo necessidade de utilizar plantas que contribuam para a resiliência dos sistemas de produção. A maniçoba é vista como um potencial recurso forrageiro no semiárido brasileiro, sendo utilizada como feno ou silagem para alimentação de ruminantes. O objetivo desta revisão foi sumarizar os resultados quanto à produção de forragem da maniçoba, além do consumo de matéria seca (MS), desempenho produtivo e qualidade dos produtos de origem animal obtidos com dietas à base de maniçoba, quando comparados com dietas compostas por outros volumosos para caprinos e ovinos. Considerando os estudos avaliados, a produtividade média da maniçoba variou de 367 a $1.592 \mathrm{~kg}$ de $\mathrm{MS} \mathrm{ha}^{-1}$, com aumento da produção de forragem pela maior fertilização da planta e densidade de plantio. As dietas à base de maniçoba promoveram resultados semelhantes ou superiores para ingestão de matéria seca e desempenho produtivo de caprinos e ovinos, quando comparadas às dietas compostas por outros recursos forrageiros. A qualidade dos produtos de origem animal também foi semelhante às proporcionadas por dietas à base de volumosos tradicionais, como feno Tifton 85 ou palma-forrageira. Portanto, a maniçoba apresenta produção de forragem que pode contribuir com os sistemas de produção de ruminantes em ambiente semiárido, e promover desempenho produtivo e qualidade dos produtos de origem animal compativeis com as proporcionadas pelas forrageiras tradicionais.

Palavras-chave: alternativa forrageira, recurso forrageiro, mandioca silvestre, Manihot, planta cianogênica.

\section{INTRODUCTION}

Food security for herds has been an important challenge for livestock production in arid and semiarid regions (MLAMBO \& MAPIYE, 2015) and there is great concern about food production to meet the demands of the world's growing population, with drylands playing a relevant role in this scenario (TARRASÓN et al., 2016). In this sense livestock systems need to improve land use by using adapted forage plants that are inserted in the socioeconomic context of the population and contribute to new strategies for supplying nutrients for ruminants, reducing production losses and increasing animal yield and farm income.

Maniçoba comprises plants (wild species) of the genus Manihot, including Manihot glaziovii Müll. Arg., Manihot catingae Ule and Manihot carthaginensis (Jacq.) Müll. Arg, all native to the Brazilian semiarid, showing genetic and 
morphoagronomic diversity (CAMPOS et al., 2020). The plants are perennial, tolerant to cuttings and long periods of drought, with morphological adaptation related to water retention (NASSAR et al., 2010), and physiological mechanisms via control of stomatal aperture to maintain a positive carbon balance even in drought conditions (MORGANTE et al., 2020). In ruminant feeding, maniçoba is used exclusively as hay or silage to reduce the toxicity of hydrocyanic acid, thus allowing a safe feeding for animals (MATOS et al., 2005; SOARES, 2000; SOUZA et al., 2006).

Productive and qualitative characteristics of the plant must be considered, along with its potential to constitute diets that provide a proper productive performance to the animal. In this sense the evaluation of yield and quality of maniçoba forage, as well as the assessment of dry matter (DM) intake, productive performance of goats and sheep, and its influence on animal product quality, are important aspects to understand the potential of this plant as an alternative for livestock production systems in semiarid environments.

The present review summarized the results of forage yield of maniçoba in the semiarid region of Brazil, the DM intake and productive performance of goats and sheep fed maniçoba-based diets, and the quality of animal products.

\section{Productivity and factors that affect the forage yield}

The results of five experimental trials ( $\mathrm{n}$ $=50$ treatments) in the Brazilian semiarid evaluated the forage production of maniçoba, considering single-crop and rainfed conditions. These studies were carried out in the states of Pernambuco and Paraíba, with cutting intervals varying from 152 to 1,095 days and accumulated rainfall in the period varying from 321 to $1,163 \mathrm{~mm}$. The average forage yield reported for maniçoba ranged from 367 to 1,592 $\mathrm{kg} \mathrm{DM}^{-1} \mathrm{ha}^{-1}$ (Table 1), considering different cutting intervals of the plant, reaching $3,733 \mathrm{~kg}$ $\mathrm{DM}^{-1} \mathrm{ha}^{-1}$ regarding the sum of the production of two consecutive harvests, performed after up to fifteen months (SOARES, 1989).

Several factors influence the production of maniçoba forage. ARAÚJO FILHO et al. (2011) verified that organic fertilization increased the yield by up to $80 \%$, in comparison to non-fertilized maniçoba, due to the nutrient supply to the crop. The increase in plant density also increased the forage yield, with plant densities reaching 6,667 (ARAÚJO FILHO et al., 2011) or 10,000 plants ha ${ }^{-1}$ (SOARES, 1989), indicating that maniçoba can respond favorably to intensive crop management.
Soil management using ridges and the cutting heights of the plants (MOREIRA FILHO et al., 2008), the water depths and the nitrogen (N) fertilization (ARAÚJO FILHO et al., 2013) are also factors that affect the plant growth and increase the forage yield. Presumably, the ridges increase the accumulation and availability of nutrients in the soil, favoring the development of the plant root system. The increase in productivity with $\mathrm{N}$ fertilization suggested that maniçoba has efficient metabolic responses to the use of this nutrient.

Beyond the forage yield, BELTRÃO et al. (2008) pointed out the proportion of leaves on the plant, reporting that approximately $50 \%$ of the produced forage $\left(\mathrm{kg} \mathrm{DM}^{-1} \mathrm{ha}^{-1}\right)$ corresponds to this component, which may still be incremented by management practices, as for instance organic fertilization.

These results denoted that maniçoba allows forage yield compatible with the semiarid environment. Therefore, it contributed to the forage input for ruminant production systems, while management factors may increase the productive efficiency of the crop.

It is important that there should be a greater number of studies evaluating this forage resource, especially including diverse locations in the semiarid region, thus enlarging the database on crop yield, above all regarding long-term studies.

\section{Forage quality}

The dry matter content of fresh maniçoba varied from 204.4 to $289.2 \mathrm{~g} \mathrm{~kg}^{-1}$ (ARAÚJO FILHO et al., 2011; SILVAet al., 2011). The chemical composition of the plant, based on data from 21 articles, reported by authors as hay, silage or fresh (in natura) maniçoba, consisted on average of crude protein (CP), ash, ether extract (EE), neutral and acid detergent fiber (NDF and ADF), hemicellulose (HEM), cellulose (CELL) and lignin, at $156.5 ; 79.4 ; 43.9 ; 473.4 ; 354.9 ; 125.3 ; 231.5$ and $109.2 \mathrm{~g} \mathrm{~kg}^{-1}$, respectively (Table 2).

Crude protein levels ranged from 90.8 to $227.5 \mathrm{~g} \mathrm{~kg}^{-1}$, and NDF varied from 355.0 to $586.0 \mathrm{~g}$ $\mathrm{kg}^{-1}$ (Table 2). The offered forms of maniçoba (fresh, hay or silage) did not result in great differences on main parameters of chemical composition. On average, fresh maniçoba showed $173.8 \mathrm{~g} \mathrm{~kg}^{-1}$ for $\mathrm{CP}$, while as hay and silage CP levels were 141.1 and $154.7 \mathrm{~g} \mathrm{~kg}^{-1}$. Additionally, NDF for fresh maniçoba was $449.8 \mathrm{~g} \mathrm{~kg}^{-1}$, while as hay and silage it was 475.5 and $494.8 \mathrm{~g} \mathrm{~kg}^{-1}$, respectively (Table 2). The authors attributed changes in chemical composition mainly to the proportion of leaf/stem (FRANÇA et al., 2010), as well as genotype and development stage of the 
Table 1 - Mean and maximum forage yield ( $\mathrm{kg} \mathrm{DM} \mathrm{ha}^{-1}$ ) of maniçoba, cutting intervals (days), municipality, and rainfall (mm/period) from studies carried out in Brazilian semiarid in rainfed condition.

\begin{tabular}{|c|c|c|c|c|}
\hline Mean productivity & ---Maximum productivity--- & ----Cutting interval---- & ---------Municipality-------- & --------Rainfall--------- \\
\hline $456^{1}$ & 626 & 240 & Areia-PB & $893.5^{*}$ \\
\hline $471^{2}$ & 1,800 & 1,095 & Cubatí-PB & 321 \\
\hline $367^{3}$ & 462 & 152 & Campina Grande-PB & 765 \\
\hline $1,178^{4}$ & 1,746 & $120-240$ & Areia-PB & $893.5-1,163$ \\
\hline $1,592^{5}$ & 3,733 & $365-456$ & Petrolina-PE & $937^{* *}$ \\
\hline
\end{tabular}

${ }^{1}$ BELTRÃO et al. (2008) ${ }^{*}$ accumulated rainfall of years 2002 and 2003 in Areia-PB from AESA (2020), ${ }^{2}$ MOREIRA FILHO et al. (2008), ${ }^{3}$ VASCONCELOS et al. (2010), ${ }^{4}$ ARAÚJO FILHO et al. (2011), ${ }^{5}$ SOARES (1989). ${ }^{* *}$ accumulated rainfall of years 1987 and 1988 in Petrolina-PE (Meteorological Station of Embrapa Semiárido).

plant (MOREIRA FILHO et al., 2009), indicating the conservation process of maniçoba as an important tool to maintain the nutrients.

Maniçoba exhibited high lignin levels, which may reduce the forage digestibility. Conversely, this forage also showed high CP and low NDF, compatible with or higher than the ones presented by other forage resources used to feed ruminants in the Brazilian semiarid. High CP and low NDF are positive aspects in roughage for feeding ruminants. SANTOS et al. (2017) evaluated different forages in natura and observed $208.0 \mathrm{~g} \mathrm{~kg}^{-1} \mathrm{CP}$ and $434.0 \mathrm{~g} \mathrm{~kg}^{-1} \mathrm{NDF}$

Table 2 - Crude protein (CP), ash, ether extract (EE), neutral detergent fiber (NDF), acid detergent fiber (ADF), hemicellulose (HEM), cellulose (CELL) and lignin (LIG) of maniçoba (in natura, hay and silage).

\begin{tabular}{|c|c|c|c|c|}
\hline \multirow{2}{*}{ Fractions } & ---------------in natura------------- & ----------------Hay----------------- & --------------Silage-------------- & \multirow{2}{*}{----Overall average---- } \\
\hline & Mean Min. - Max. & Mean Min. - Max. & Mean Min. - Max. & \\
\hline \multirow{2}{*}{$\mathrm{CP}$} & 173.8 & 141.1 & 154.7 & \multirow{2}{*}{156.5} \\
\hline & $110.9-227.5^{1,2,3,4,5,6,7,8,9,10,11}$ & $90.8-196.0^{2,12,13,14,15,16,17}$ & $125.0-188.0^{5,6,18,19,20,21}$ & \\
\hline \multirow{2}{*}{ Ash } & 76.4 & 76.9 & 85.0 & \multirow{2}{*}{79.4} \\
\hline & $61.0-142.8^{2,3,4,5,6,8,10,11}$ & $61.7-99.5^{2,12,13,15,16,17}$ & $71.5-97.8^{5,6,18,19,20,21}$ & \\
\hline \multirow{2}{*}{$\mathrm{EE}$} & 42.1 & 50.3 & 39.3 & \multirow{2}{*}{43.9} \\
\hline & $20.6-102.0^{1,2,3,4,5,6,7,9,10,11}$ & $22.0-99.6^{2,12,13,14,15,17}$ & $29.8-62.0^{5,6,18,19,20,21}$ & \\
\hline \multirow{2}{*}{ NDF } & 449.8 & 475.5 & 494.8 & \multirow{2}{*}{473.4} \\
\hline & $359.0-557.1^{1,2,3,4,5,6,7,8,9,11}$ & $355.0-586.0^{2,12,13,14,17}$ & $400.2-584.5^{, 6,20,21}$ & \\
\hline \multirow{2}{*}{$\mathrm{ADF}$} & 337.3 & 351.8 & 375.7 & \multirow{2}{*}{354.9} \\
\hline & $264.5-466.5^{1,3,4,5,6,7,8,9,10,11}$ & $279.0-462.7^{2,12,13,14,15,16,17}$ & $264.6-473.0^{5,6,20,21}$ & \\
\hline \multirow{2}{*}{ HEM } & 129.0 & 113.0 & 133.9 & \multirow{2}{*}{125.3} \\
\hline & $95.0-189.8^{1,4,8,10}$ & $113.0-113.0^{12}$ & $57.0-210.8^{6,19}$ & \\
\hline \multirow{2}{*}{ CELL } & 197.1 & 258.7 & 238.6 & \multirow{2}{*}{231.5} \\
\hline & $116.2-242.0^{1,4,10}$ & $230.3-287.0^{12,14}$ & $191.2-286.0^{6,19}$ & \\
\hline \multirow{2}{*}{ LIG } & 106.6 & 113.1 & 108.0 & \multirow{2}{*}{109.2} \\
\hline & $65.1-141.4^{2,3,4,6,7}$ & $93.0-171.0^{2,12,14,15,16,17}$ & $78.5-182.0^{6,19,20,21}$ & \\
\hline
\end{tabular}

Source: ${ }^{1}$ BELTRÃO et al. (2015); ${ }^{2}$ FRANÇA et al. (2010); ${ }^{3}$ DANTAS et al. (2008); ${ }^{4}$ CAMPOS et al. (2020); ${ }^{5}$ SOUZA et al. (2006); ${ }^{6}$ BACKES et al. (2014); ${ }^{7}$ SILVA et al. (2011); ${ }^{8}$ VASCONCELOS et al. (2010); ${ }^{9}$ MATOS et al. (2005); ${ }^{10}$ SANTOS et al. (2017);

${ }^{11}$ CARVALHO et al. (2018); ${ }^{12}$ BARROS et al. (1990); ${ }^{13}$ MOURA et al. (2020); ${ }^{14}$ CASTRO et al. (2007); ${ }^{15}$ MENEZES et al. (2012);

${ }^{16}$ SANTOS et al. (2021); ${ }^{17}$ COSTA et al. (2008); ${ }^{18}$ MACIEL et al. (2019); ${ }^{19}$ MATIAS et al. (2020); ${ }^{20}$ SOARES II et al. (2017); ${ }^{21}$ LOIOLA FILHO et al. (2012). 
for maniçoba, while Cunhã (Clitorea ternatea L.), Sabiá (Mimosa caesalpiniifolia Benth.), Gliricídia (Gliricidia sepium (Jacq.) Steud.) and Mororó (Bauhinia cheilanta (Bong.) Steud.) presented 148.0; 124.0; 175.0; and $115.0 \mathrm{~g} \mathrm{~kg}^{-1} \mathrm{CP}$ and 604.0, 679.0, 510.0 and $683.0 \mathrm{~g} \mathrm{~kg}^{-1} \mathrm{NDF}$, respectively.

The nutritional value of maniçoba is influenced by divers factors, such as chemical fertilization, soil types and management, plant cutting height and stage of development of the plant (ANDRADE et al., 2014; MOREIRA FILHO et al., 2009). In a study carried out by PARENTE et al. (2007), maniçoba in natura showed $13.91 \%$ CP when supplied with $100 \mathrm{~kg} \mathrm{~N} \mathrm{ha}^{-1}$, while without nitrogen fertilization the CP content was $8.58 \%$,

According to MENEZES et al. (2012), the potential DM degradability of maniçoba hay was $70 \%$, while the effective degradability $(5 \% / \mathrm{h})$ was $57.4 \%$. The potential degradability of CP was $92.5 \%$ and the effective one $(5 \% / \mathrm{h})$ was $80 \%$. SOUZA et al. (2006) reported a potential degradability of NDF varying from 52.12 to $54.45 \%$, with an effective degradability $(5 \% / \mathrm{h})$ varying from 32.41 to $32.55 \%$.

FRANÇA et al. (2010) observed that the DM degradability is related to a great participation of leaves in the produced biomass, presenting tissues with less thickened walls and lower lignification, promoting higher degradability than the stem part. These authors also reported that the main factor promoting low degradability of NDF was the thickening and lignification of cell walls, especially in stem tissues.

Macromineral levels in maniçoba are shown in table 3. Nitrogen and potassium presented the greatest contents, followed by calcium and magnesium. According to ANDRADE et al. (2014), N and $\mathrm{K}$ levels of maniçoba are influenced by the stage of leaf development and the plant location. They observed $\mathrm{N}$ and $\mathrm{K}$ differences in the leaves at the beginning of the senescence process compared with expanding or completely expanded leaves, attributed to the nutrient translocation, especially $\mathrm{N}$ from old to new leaves. In addition, $\mathrm{N}$ and $\mathrm{K}$ contents differed according to the municipality of origin of the maniçoba sample, associated with soil and climatic characteristics.

Sodium, iron, zinc, and manganese were the main microminerals presented by maniçoba (Table 4). Mineral elements exert an important role in the plant, including structural functions and metabolic process, and they are also essential for animals. The insufficiency of even one element may negatively affect animal growth, as well as health and reproductive functions. In the Brazilian semiarid the main source of minerals for ruminants is forage, and the supply of minerals through maniçoba forage contributes to meeting the requirements for these elements.

Furthermore, the knowledge of mineral contents in maniçoba enables the comprehension of extraction and exportation of nutrients by the plant, and determines the mineral reposition, according to the forage yield.

As secondary compounds, da SILVA (2016) reported the presence of steroids, saponins, tannins and flavonoids in maniçoba leaves, with differences in concentration among evaluated accessions and leaf maturation stages. In addition, BELTRÃO et al. (2015) reported total tannins varying from 0.2 to $5.3 \% \mathrm{DM}$ and $\mathrm{HCN}$ ranging from 97.2 to $291.6 \mathrm{mg} \mathrm{kg}^{-1} \mathrm{DM}$ in maniçoba, while FRANÇA et al. (2010) observed tannin levels of 1.58 and $1.87 \% \mathrm{DM}$, respectively for maniçoba in natura or hay, and reported an important antinutritional action when they exceeded 5\% DM in

Table 3 - Content of macrominerals in maniçoba in natura, subject to fertilization, pruning and different planting spacings.

\begin{tabular}{|c|c|c|c|}
\hline \multirow[t]{2}{*}{ Mineral } & \multicolumn{3}{|c|}{ 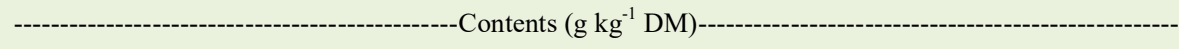 } \\
\hline & ----------------Mean--------------- & ------'-------Minimum------------ & 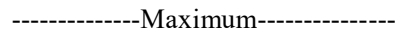 \\
\hline Nitrogen ${ }^{1,2}$ & 30.74 & 17.26 & 40.30 \\
\hline Phosphorus ${ }^{4}$ & 2.54 & 1.46 & 4.28 \\
\hline Potassium $^{4}$ & 13.75 & 4.10 & 20.48 \\
\hline Calcium $^{3}$ & 4.65 & 3.54 & 13.50 \\
\hline Magnesium $^{3}$ & 4.45 & 3.60 & 5.45 \\
\hline Sulfur ${ }^{2}$ & 1.85 & 1.80 & 1.90 \\
\hline
\end{tabular}

Sources: ${ }^{1,4}$ ANDRADE et al. (2014); ${ }^{1,2,3,4}$ ARAÚJO FILHO et al. (2011); ${ }^{3,4}$ FERREIRA et al. (2009); ${ }^{3,4}$ PARENTE et al. (2007). 
Table 4 - Micromineral contents in maniçoba genotypes, in natura, cut at intervals of six months of regrowth.

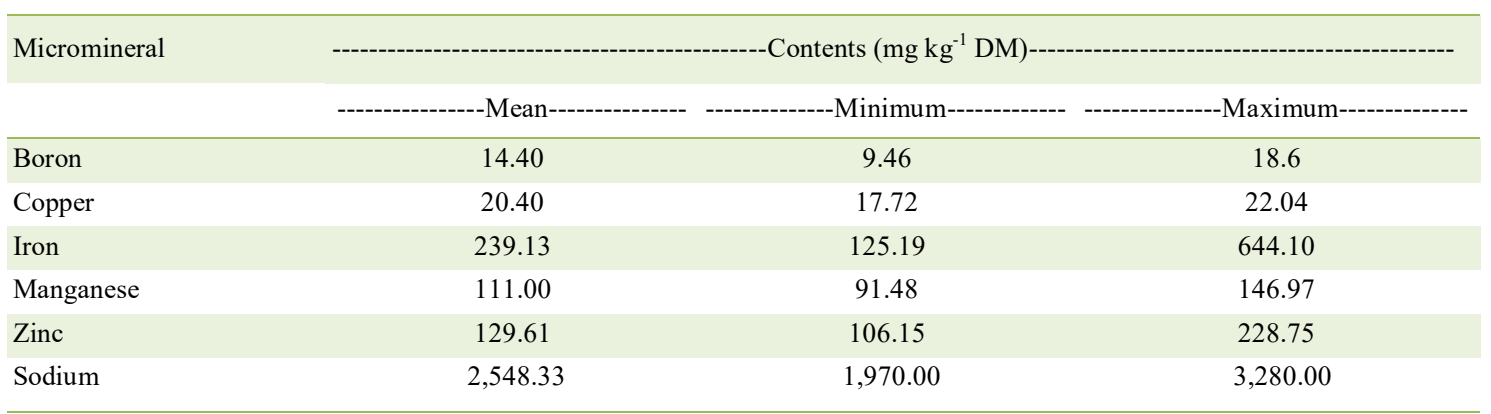

Source: LIMA (2019).

diets, indicating there is no negative effect of tannin levels presented by maniçoba on DM digestibility.

The high presence of cyanogenic glycosides in maniçoba, when hydrolyzed, release hydrocyanic acid (HCN) through the action of enzymes such as ß-glucosidase (linamarinase), which may be poisonous to animals, depending on the ingested quantity. Ingestion greater than $2.4 \mathrm{mg}$ of $\mathrm{HCN} / \mathrm{kg}$ of body weight may cause several disorders (SOARES, 2000).

SOUZA et al. (2006) verified $972 \mathrm{mg} \mathrm{kg}^{-1}$ of $\mathrm{HCN}$ in maniçoba in natura (\% DM) and $162 \mathrm{mg}$ $\mathrm{kg}^{-1}$ in silage (\% DM), while SOARES (2000) reported a reduction in $\mathrm{HCN}$ by over $65 \%$ in maniçoba silage after the first 29 days of ensilage, reaching a reduction of up to $78 \%$ after 174 days. According to MATOS et al. (2005) the enzyme linamarinase is inactivated by heat and the ensiling process also contributes to the fermentation of glycosides by anaerobic microorganisms, reducing $\mathrm{HCN}$ concentration.

Maniçoba silage can be made without using additives promoting a proper fermentation process to the ensiling mass, showing aerobic stability for up to 14 days after silo opening (SOUZA et al., 2006); although, the use of additives, such as corn meal, can contribute to the quality of the silage (BACKES et al., 2014).

Similarly, FRANÇA et al. (2010) reported $\mathrm{HCN}$ values of 512.83 and $86.34 \mathrm{mg} \mathrm{kg}^{-1} \mathrm{DM}$ for maniçoba in natura or hay, respectively. During the haying process, the plant is chopped and dehydrated promoting the $\mathrm{HCN}$ volatilization by the action of sunlight and wind (ARAÚJO et al., 2004). The use of maniçoba silage or hay did not affect the DMI and the average daily gain of sheep (MACIEL et al., 2019). Therefore, both conservation strategies (hay or silage) can be offered to ruminants, seeing that they are also important to reduce $\mathrm{HCN}$ levels in the forage, providing safe feed.

The chemical composition of maniçoba offers opportunities to perform studies aiming the evaluation and selection of genotypes with lower concentrations of hydrocyanic acid and lignin, and greater degradability of fiber, as well as the evaluation of crop management practices that increase the degradability of the fibrous fraction.

Dry matter intake and productive performance of goats and sheep

Dry matter intake (DMI) data for goats and sheep fed on maniçoba based diets (hay or silage) were obtained from 13 studies $(n=46$ treatments). In four of them maniçoba was compared to other roughages (Table 5), while in nine increasing levels of this forage in diets were evaluated, replacing roughages (MENDONÇA JÚNIOR et al., 2008; MOURA et al., 2020) or concentrates (CASTRO et al., 2007; ARAÚJO et al., 2009a) (Table 6).

Maniçoba diets promoted similar DMI compared to diets composed by others roughages offered to goats and sheep, and even higher DMI when compared to feed based on hay from feijão-bravo (Capparis flexuosa L.) and gliricidia (Table 5), which might be associated to the presence of anti-nutritional factors, such as tannins and coumarins, respectively, impairing the acceptance of the feed by the animals (LIMA JÚNIOR et al., 2014; MOREIRA et al., 2008). In addition, MACIEL et al. (2019) reported greater DMI by sheep fed maniçoba hay based diets compared to a Tifton 85 based diet (Table 5).

On average, DMI promoted by maniçoba diets was $4.30 \%$ body weight (BW), ranging from 2.85 
Table 5 - Dry matter intake (DMI) of goats and sheep fed diets based on maniçoba in comparison to diets based on the other roughages.

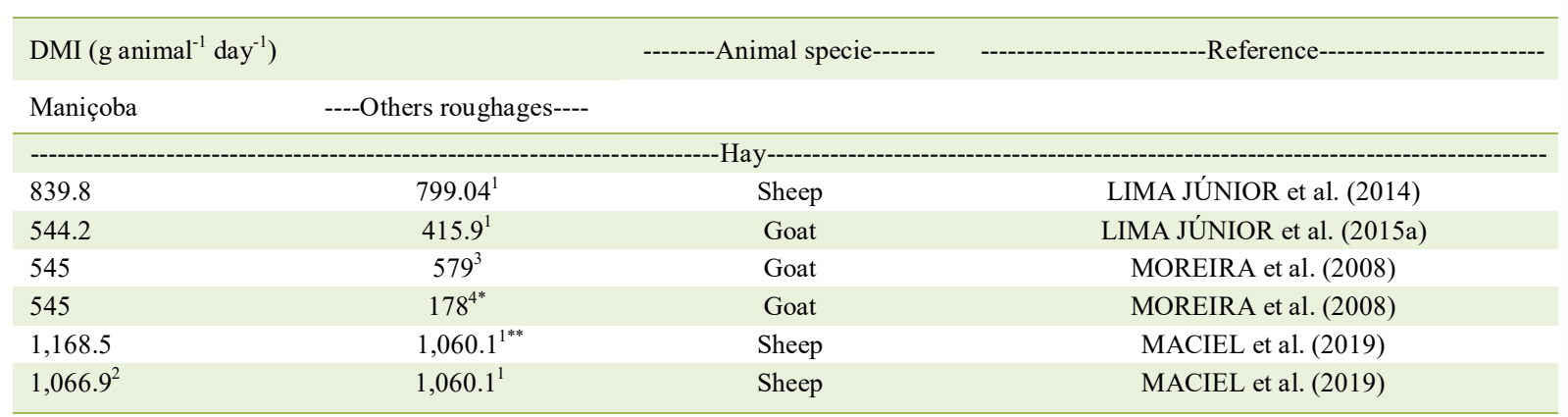

${ }^{1}$ Tifton 85 grass; ${ }^{2}$ Maniçoba silage; ${ }^{3}$ Leucaena; ${ }^{4}$ Gliricidia. $30 \%$ DM of maniçoba in diets (MACIEL et al., 2019; MOREIRA et al., 2008), 40\% DM of maniçoba in diets (LIMA JÚNIOR et al., 2014, 2015a), "maniçoba hay had greater DMI compared to gliricidia hay. maniçoba hay had greater DMI than tifton 85 hay.

to $5.40 \%$ BW (ARAÚJO et al., 2004; CASTRO et al., 2007; SILVA et al., 2007; MENDONÇA JÚNIOR et al., 2008; ARAÚJO et al., 2009a; MOURA et al., 2020).

Increasing maniçoba (\% DM) in diets promoted greater DMI (ARAÚJO et al., 2004) or did not alter the DMI of sheep and goats (Table 6), indicating this roughage can be included in considerable proportion in diets, without harming the DMI.

Five studies evaluated the average weight gain (ADG) (CASTRO et al., 2007; LIMA JÚNIOR et al., 2014; MACIEL et al., 2019; MOREIRA et al., 2008) of sheep or goats, comparing maniçoba based diets to rations comprising other roughages, or assessing increasing levels of maniçoba in diets (Table 7).

In one of those studies, comparing maniçoba hay with Tifton 85 in diets for Moxotó goats, LIMA JÚNIOR et al. (2015a) reported that animals fed with this roughage had $-9 \mathrm{~g} \mathrm{day}^{-1}$ of body weight variation, while the Tifton 85 based diet (control diet) promoted $10 \mathrm{~g} \mathrm{day}^{-1}$ of weight gain (Table 7), without statistical difference for diets. The authors attributed the low ADG promoted by both diets to a lack of adaptation of the animals to the feedlot management, because they had come from an extensive production system, in addition to the advanced age of the animals, and the low DMI presented by goats.

The productive performance of animals receiving maniçoba diets was similar when compared to the other roughages or increasing levels of this roughage in diets in all studies, except MOREIRA et al. (2008), who observed greater ADG for goats fed on a diet based on maniçoba hay compared to a gliricidia based diet, due to the greater DMI (Table 7). The food consumption of animals fed maniçoba diets is an important factor influencing the productive performance, seeing that DMI determines the supply of nutrients. Diets composed of maniçoba provided up to $290 \mathrm{~g} \mathrm{day}^{-1}$ of weight gain for feedlot sheep, including 20 to $40 \%$ DM (CASTRO et al., 2007) or $30 \%$ DM of this roughage (CARTAXO et al., 2008). In addition, one study evaluated milk yield of goats fed increasing levels of maniçoba in diets (30 to 60\% DM) (ARAÚJO et al., 2009b).

The results for productive performance of sheep and goats fed maniçoba diets demonstrate weight gain compatible to the one promoted by diets comprising traditional roughages, and enable the inclusion of considerable levels of this plant in animal diets. In addition, other research fronts are important to be pursued, providing a better understanding of the maniçoba based diets for ruminants, regarding the methane emission and the interactions of nutrition and immunological or reproductive responses.

\section{Quality of animal products}

Using maniçoba for sheep did not result in changes in carcass traits (LIMA JÚNIOR et al., 2014; MACIEL et al., 2015) and non-carcass components yield (MACIEL et al., 2015) when compared to Tifton 85 hay based diets, neither were there changes in the yield of "buchada" and "panelada" (typical dishes using organs and viscera) (LIMA JÚNIOR et al., 2015a).

Increasing maniçoba in diets (35 - 70\%) for Moxotó and Canindé goats did not alter the centesimal composition, final $\mathrm{pH}$ and color of the meat (LISBOA et al., 2010), evincing proper digestive and metabolic responses. The replacement of spineless cactus by maniçoba in sheep diets did not change the physicalchemical composition of the meat, its color or the weight loss in cooking (MOURA et al., 2020). 
Table 6 - Intake of dry matter for sheep or goats receiving diets composed by maniçoba in different levels of inclusion (\% DM - Dry matter).

\begin{tabular}{|c|c|c|c|}
\hline Levels (\% DM) & -----Dry Matter Intake $\left(\mathrm{g} \mathrm{day}^{-1}\right)$---- & -------Animal specie------- & 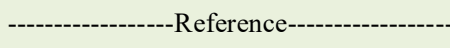 \\
\hline & 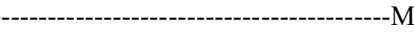 & niçoba hay------------------- & 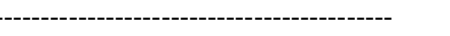 \\
\hline 30 & 591.0 & \multirow{5}{*}{ Sheep } & \multirow{5}{*}{ ARAÚJO et al. (2004) ${ }^{1^{*}}$} \\
\hline 40 & 604.0 & & \\
\hline 50 & 633.0 & & \\
\hline 60 & 683.0 & & \\
\hline 70 & 710.0 & & \\
\hline 20 & 1240.0 & \multirow{4}{*}{ Sheep } & \multirow{4}{*}{ SILVA et al. $(2007)^{1}$} \\
\hline 40 & 1240.0 & & \\
\hline 60 & 1200.0 & & \\
\hline 80 & 1300.0 & & \\
\hline 20 & 1160.0 & \multirow{4}{*}{ Sheep } & \multirow{4}{*}{ CASTRO et al. $(2007)^{1}$} \\
\hline 40 & 1280.0 & & \\
\hline 60 & 1220.0 & & \\
\hline 80 & 1190.0 & & \\
\hline 30 & 1940.0 & \multirow{4}{*}{ Goat } & \multirow{4}{*}{ ARAÚJO et al. (2009a) ${ }^{1}$} \\
\hline 40 & 2060.0 & & \\
\hline 50 & 1910.0 & & \\
\hline 60 & 1910.0 & & \\
\hline 0 & 845.8 & \multirow{3}{*}{ Sheep } & \multirow{3}{*}{ MENDONÇA JÚNIOR et al. $(2008)^{2}$} \\
\hline 50 & 912.8 & & \\
\hline 100 & 960.6 & & \\
\hline 0 & 1290.0 & \multirow{4}{*}{ Sheep } & \multirow{4}{*}{ SANTOS et al. $(2021)^{1}$} \\
\hline 10 & 1270.0 & & \\
\hline 20 & 1240.0 & & \\
\hline 30 & 1430.0 & & \\
\hline 0 & 1022.8 & \multirow{4}{*}{ Sheep } & \multirow{4}{*}{ MOURA et al. $(2020)^{1}$} \\
\hline 20 & 1146.0 & & \\
\hline 40 & 1183.4 & & \\
\hline 60 & 1134.8 & & \\
\hline \multicolumn{3}{|c|}{ 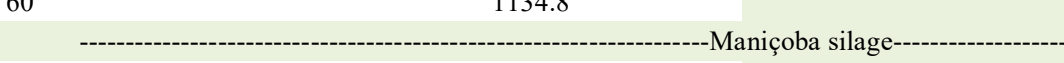 } & \multirow{5}{*}{ LOIOLA FILHO et al. $(2012)^{1}$} \\
\hline 60 & 470.0 & \multirow{4}{*}{ Goats } & \\
\hline 70 & 500.0 & & \\
\hline 80 & 470.0 & & \\
\hline 90 & 430.0 & & \\
\hline 25 & 957.0 & \multirow{4}{*}{ Goats } & \multirow{4}{*}{ MATIAS et al. $(2020)^{2^{*}}$} \\
\hline 50 & 1113.0 & & \\
\hline 75 & 1127.0 & & \\
\hline 100 & 1220.0 & & \\
\hline
\end{tabular}

"Indicates crescent linear DMI with inclusion of maniçoba; ${ }^{1}$ Levels of maniçoba in diets; ${ }^{2}$ Levels of maniçoba replacing the roughage portion in diets. *Diet exclusively composed by roughages.

MOURA et al. (2020), based on sensory evaluation of lamb meat, reported greater purchase intention for meat of lambs fed on diets with greater inclusion of maniçoba in comparison to the spineless cactus based diets, evincing greater consumer preference, indicating the meat of lambs fed maniçoba hay diets has adequate equilibrium in sensory parameters as color, aroma, tenderness, juiciness, and flavor. Additionally, MADRUGA et al. (2006) reported adequate polyunsaturated fatty acid levels and polyunsaturated / saturated fatty acids for sheep fed maniçoba diets.

An inclusion of maniçoba of up to $60 \%$ $\mathrm{DM}$ in diets for lactating goats did not modify the physical-chemical composition (proteins, fat, 
Table 7 - Productive performance (weight gain or milk yield) of sheep and goats fed on diets comprising maniçoba compared to others roughages or increasing maniçoba levels in diets.

\begin{tabular}{|c|c|c|c|c|}
\hline Animal specie & -----Maniçoba----- & -------Others roughages------ & -Inclusion level (\% DM)- & ---------------Reference---------------- \\
\hline Sheep & $122.0^{5}$ & $139.0^{1,5}$ & 40 & LIMA JÚNIOR et al. (2015b) \\
\hline Sheep & $146.1^{8}$ & $153.3^{1}$ & 30 & \\
\hline Sheep & 135.3 & $153.3^{1}$ & 30 & MACIEL et al. (2019) \\
\hline \multirow{3}{*}{ Goat } & $181 \mathrm{a}$ & $187 \mathrm{a}^{2}$ & 30 & \multirow{3}{*}{ MOREIRA et al. (2008) } \\
\hline & $181 \mathrm{a}$ & $60 b^{3}$ & 30 & \\
\hline & $181 \mathrm{a}$ & $50 b^{4}$ & 30 & \\
\hline Goat & $-9.0^{7}$ & $10.0^{1}$ & 40 & LIMA JÚNIOR et al. (2015a) \\
\hline \multirow{4}{*}{ Sheep } & 290.84 & - & 20 & \multirow{4}{*}{ CASTRO et al. $(2007)^{*}$} \\
\hline & 293.62 & - & 40 & \\
\hline & 253.35 & - & 60 & \\
\hline & 208.48 & - & 80 & \\
\hline ------------------ & ------------------------ & --------------Milk yield, kg & 1y & ----------------------------------. \\
\hline \multirow{4}{*}{ Goat } & 1.40 & - & 30 & \multirow{4}{*}{ ARAÚJO et al. (2009b) } \\
\hline & 1.45 & - & 40 & \\
\hline & 1.33 & - & 50 & \\
\hline & 1.36 & - & 60 & \\
\hline
\end{tabular}

${ }^{1}$ Tifton 85 grass; ${ }^{2}$ Leucaena; ${ }^{3}$ Caatinga (native vegetation); ${ }^{4}$ Gliricidia. In line, means followed by different lowercase letters differs by Tukey test $(P<0.05)$. ${ }^{*}$ indicates a linear decreasing on daily gain with greater inclusion of maniçoba. ${ }^{5}$ Calculated as follow (weight at slaughter - initial body weight) / number of days.

lactose, dry extract, density and acidity) of the milk (ARAÚJO et al., 2009b; COSTA et al., 2008), nor the fatty acid contents (saturated, monounsaturated and polyunsaturated) (MESQUITA et al., 2008), or the sensorial parameters (odor, taste and overall appearance) (COSTA et al., 2008).

Therefore, the use of maniçoba for goats and sheep has not promoted changes in qualitative parameters of animal products, especially meat and milk, compared to traditional roughages. Further studies are important to increase the database for this forage plant on quality of animal origin products.

\section{CONCLUSION}

Maniçoba presents forage productivity that may contribute to livestock production systems in the Brazilian semiarid, besides providing forage with adequate nutritional value. Its use in diets for sheep and goats has allowed dry matter intake, productive performance, and quality animal products similar to the ones provided by traditional forage resources, such as Tifton 85 or spineless cactus, reinforcing the possibility of its use in the sheep and goat production systems.

\section{ACKNOWLEDGEMENTS}

We thank FACEPE for the scholarship of the first author IBPG-1424-5.04/18. This study was also financed in part by the Coordenação de Aperfeiçoamento de Pessoal de Nível Superior (CAPES), Brasil- Finance code 001.

\section{DECLARATION OF CONFLICT OF INTERESTS}

The authors declare no conflict of interest.

\section{AUTHORS' CONTRIBUTIONS}

The author M L R Gomes was responsible for structuring the manuscript. The authors M L R Gomes and L C Souza wrote topic 2 (Productivity and factors that affect the yield). The authors F C Alves, C M Souza and M N P Silva wrote the topics 3 (Forage quality) and 4 (Dry matter intake and productive performance of goats and sheep). The authors J R V Silva Filho and R A Santana Júnior wrote topic 5 (Quality of animal products). The author $\mathrm{T} \mathrm{V}$ Voltolini was responsible for correcting all topics and structuring the manuscript.

\section{REFERENCES}

AESA. Agência executiva de gestão das águas. Available from: $\quad<$ http://www.aesa.pb.gov.br/aesa-website/meteorologia- 
chuvas-grafico/?id_municipio $=15 \&$ date_chart $=2002-05$ 31\&period=month $>$. Accessed: Dec. 4, 2020.

ANDRADE, A. P. et al. Chemical-nutritional composition of maniçoba (Manihot sp.) and its relationship with soil chemical characteristics. Revista Brasileira de Zootecnia, v. 43, n. 4, p. 161-168, 2014. Available from: <https//doi.org/10.1590/S151635982014000400001>. Accessed: Oct. 6, 2020.

ARAÚJO FILHO, J. T. et al. Morphological characteristics and nutritional value of cassava under planting spacing and fertilization. Revista Brasileira de Saúde e Produção Animal, v. 12, n. 3, p. 2078-2078, 2011. Available from: <https://doi.org/10.1590/ S1519-99402013000400001>. Accessed: May. 4, 2020.

ARAÚJO FILHO, J. T. et al. Morphological and productive characteristics of cassava grown under irrigation and nitrogen levels. Revista Brasileira de Saúde e Producao Animal, v. 14, n. 4, p. 609-623, 2013. Available from: < https://doi.org/10.1590/ S1519-99402013000400001>. Accessed: May. 4, 2020.

ARAÚJO, G. G. L. et al. Voluntary intake and performance of lambs fed with different maniçoba hay dietary levels. Revista Ciência Agronômica, v. 35, n. 1, p. 123-130, 2004. Available from: $\quad<\mathrm{http}$ ://www.cpatsa.embrapa.br/public_eletronica/ downloads/OPB1177.pdf>. Accessed: Nov. 12, 2020.

ARAÚJO, M. J. et al. Intake and digestibility of nutrients in Moxotó dairy goats fed diets with different Maniçoba hay levels. Revista Brasileira de Zootecnia, v. 38, n. 6, p. 1088-1095, 2009a. Available from: <http://dx.doi.org/10.1590/S151635982009000600017>. Accessed: Oct. 20, 2020.

ARAÚJO, M. J. et al. Milk yield and composition of Moxoto goats diets containing maniçoba hay (" Manihot glaziovii " Muel Arg .) Revista Brasileira de Saúde e Produção Animal, v. 10, n. 4, p. 860-873, 2009b. Available from: <https://periodicos.ufba.br/index.php/ rbspaindex.php/rbspa/article/view/1258/914> . Accessed: Oct. 20, 2020.

BACKES, A. A. et al. Nutritional value of maniçoba ("Manihot pseudoglaziovii") silage with and without corn meal as additive. Revista Brasileira de Saúde e Produção Animal, v. 15, n. 1, p. 182-191, 2014. Available from: <https://doi.org/10.1590/S151999402014000100016>. Accessed: Nov. 12, 2020.

BARROS, N. N. et al. Nutritive value of "Maniçoba" for sheep and goat. Pesquisa Agropecuaria Brasileira, v. 25, n. 3, p. 387392, 1990. Available from: <http://marefateadyan.nashriyat.ir/ node/150>. Accessed: Apr. 15, 2021.

BELTRÃO, F. A. S. et al. Behavior of the maniçoba (Manihott Pseudoglaziovii muell arg) under diferent densities and fertilization. Revista Caatinga, v. 21, n. 4, p. 163-166, 2008. Available from: $<$ https://periodicos.ufersa.edu.br/index.php/caatinga/article/ view/151/pdf $>$. Accessed: Oct. 6, 2020.

BELTRÃO, S. et al. Chemical characterization of different sorts of maniçoba (Manihot Pseudglaziovii Pax and Hoffm) of interest forage. Engenharia Ambiental, v. 12, n. 2, p. 135-142, 2015. Available from: <http://ferramentas.unipinhal.edu.br/ engenhariaambiental/viewarticle.php?id=1247. Accessed: Dec. 2, 2020 .

CAMPOS, F. S. et al. Morpho-agronomic parameters, chemical composition and genetic divergence among Manihot sp. access Research, Society and Development, v. 9, n. 7, p. 1-21, 2020.
Available from: <http://dx.doi.org/10.33448/rsd-v9i7.4864>. Accessed: Dec. 2, 2020.

CARTAXO, F. Q. et al. Effects of genotype group and of the body condition. Revista Brasileira de Zootecnia, v. 37, n. 8, p. 1483-1489, 2008. Available from: <https://doi.org/10.1590/S151635982008000800021>. Accessed: Abr. 20, 2021.

CASTRO, J. M. C. et al. Performance of Santa Inês lambs fed total mixed rations containing different ratios of concentrate to ceara rubbertree hay. Revista Brasileira de Zootecnia, v. 36, n. 3, p. 674-680, 2007. Available from: <http://dx.doi.org/10.1590/S151635982007000300022>. Accessed: Nov. 12, 2020.

COSTA, R. G. et al. Sensorial and chemical characteristics of the milk of Moxotó goats fed with maniçoba silage. Revista Brasileira de Zootecnia, v. 37, n. 4, p. 694-702, 2008. Available from: <http://dx.doi.org/10.1590/S1516-35982008000400016>. Accessed: Nov. 12, 2020.

FERREIRA, A. L. et al. Production and nutritional value of shoot area of cassava, maniçoba, and pornunça. Revista Brasileira de Saúde e Produção Animal, v. 10, n. 1, p. 129-136, 2009. Available from: $<$ http://www.cpatsa.embrapa.br/public_eletronica/ downloads/OPB2286.pdf>. Accessed: Oct. 14, 2020.

FRANÇA, A. A. et al. Anatomy and kinetics of degradation of Manihot glaziovii Hay. Acta Scientiarum - Animal Sciences, v. 32, n. 2, p. 131-138, 2010. Available from: <https://doi.org/10.4025/ actascianimsci.v32i2.8800>. Accessed: Dec. 03, 2020.

LIMA, A. E. S. Produção, respostas morfofisiológicas, composição química e cinética de fermentação de acessos de plantas do gênero Manihot. 2019. 42f. Dissertação (Mestrado em Ciências Veterinárias do Semiárido) - Programa de Pós-graduação em Ciências Veterinárias do Semiárido, Universidade Federal do Vale do São Francisco.

LIMA JÚNIOR, D. M. et al. Effect of the replacement of Tifton 85 with maniçoba hay on the performance of Morada Nova hair sheep. Tropical Animal Health and Production, v. 46, p. 9951000, 2014. Available from: < https://doi.org/10.1007/s11250-0140600-y>. Accessed: Dec. 16, 2020.

LIMA JÚNIOR, D. M. et al. Maniçoba hay feeding Moxotó goats. Semina: Ciencias Agrarias, v. 36, n. 3, p. 22112222, 2015a. Available from: <http://doi.org/10.5433/16790359.2015v36n3Supl1p2211>. Accessed: Jan. 12, 2020.

LIMA JÚNIOR, D. M. et al. Body weight components of Morada Nova haier sheep fed Maniçoba or Tifton hay. Revista Caatinga, v. 28, n. 1, p. 239-246, 2015b. Available from: <https://periodicos.ufersa.edu.br/ index.php/caatinga/article/view/3657>. Accessed: Jan. 12, 2020.

LISBOA, A. C. C. et al. Quality assessment of goat meat of breeds native fed diets with two levels of Maniçoba hay. Revista Brasileira de Saúde e Produção Animal, v. 11, n. 4, p. 10461055, 2010. Available from: $<$ https://periodicos.ufba.br/index.php/ rbspa/article/view/40375/22473>. Accessed: Feb. 09, 2020.

MACIEL, M. DO V. et al. Maniçoba hay or silage replaces Tifton 85 hay in spineless cactus diets for sheep. Acta Scientiarum - Animal Sciences, v. 41, n. 1, p. 1-6, 2019. Available from: <http://doi. org/10.4025/actascianimsci.v41i1.42553>. Accessed: Mar. 27, 2020.

MACIEL, M. DO V. et al. Carcass and non-carcass characteristics of sheep fed on cassava (Manihot pseudoglaziovii Pax \& K. 
Hoffm.). Chilean Journal of Agricultural Research, v. 75, n. 3, p. 307-312, 2015. Available from: <http://dx.doi.org/10.4067/ S0718-58392015000400006>. Accessed: Mar. 27, 2020.

MADRUGA, M. S. et al. Effect of genotype and sex on chemical composition and fatty acid profile of sheep meat. Revista Brasileira de Zootecnia, v. 35, n. 4 suppl, p. 1838-1844, 2006. Available from: <http://dx.doi.org/10.1590/S1516-35982006000600035>. Accessed: Apr. 30, 2020.

MATOS, D. S. DE et al. Chemical composition and nutritional value of the maniçoba silage (Manihot Epruinosa). Archivos de Zootecnia, v. 54, n. 208, p. 619-629, 2005. Available from: < http://www.redalyc. org/articulo.oa?id=49520804>. Accessed: Apr. 12, 2021.

MENDONÇA JÚNIOR, A. F. et al. Evaluation of the chemical composition, Intake and in vivo digestibilidade of the diets with different levels of maniçoba hay (Manihot glaziovii Muell. Arg.), fed to sheep. Revista de Biologia e Ciências da Terra, v. 8, n. 1, p. 32-41, 2008. Available from: <https://www.redalyc.org/articulo. oa? $\mathrm{id}=50080103>$. Accessed: May. 29, 2020.

MENEZES, D. R. et al. Kinects of degradation in nutritional fractions of euphorbiaceous. Revista Brasileira de Saude e Producao Animal, v. 13, n. 2, p. 424-432, 2012. Available from: <http://dx.doi.org/10.1590/S1519-99402012000200011>. Accessed: Sep. 12, 2020.

MESQUITA, Í. V. U. et al. Profile of milk fatty acids from Moxotó goats fed with different levels of manicoba (Manihot glaziovii Muel Arg.) silage. Brazilian Archives of Biology and Technology, v. 51, n. 6, p. 1163-1169, 2008. Available from: $<$ https://doi.org/10.1590/S1516-89132008000600011>. Accessed: Aug. 19, 2020.

MLAMBO, V.; MAPIYE, C. Towards household food and nutrition security in semi-arid areas: What role for condensed tannin-rich ruminant feedstuffs? Food Research International, v. 76, n. P4, p. 953-961, 2015. Available from: < $\mathrm{https}$ ://doi.org/10.1016/j. foodres.2015.04.011>. Accessed: Jun. 7, 2020.

MOREIRA FILHO, E. C. et al. Vegetative growing of manicoba subjected at different soil management, planting densities and cutting heigth. Revista Caatinga, v. 21, n. 4, p. 147153, 2008. Available from: $<$ http://www.redalyc.org/articulo. oa? $\mathrm{id}=237117689022>$. Accessed: Dec. 1, 2020.

MOREIRA FILHO, E. C. et al. Chemical composition of manicoba subjeted to soil management differencies, planting densities and cutting heights. Revista Caatinga, v. 22, n. 2, p. 187-194, 2009. Available from: <http://www.redalyc.org/articulo. oa? id=237117689022>. Accessed: Dec. 1, 2020.

MOREIRA, J. N. et al. Roughages alternatives for growing goats. Revista Brasileira de Saúde e Produção Animal, v. 9, n. 3, p. 1398-1398, 2008. Available from: <https://www.cabdirect.org/ cabdirect/abstract/20093272543>. Accessed: Nov. 14, 2020.

MORGANTE, C. V. et al. Genetic and physiological analysis of early drought response in Manihot esculenta and its wild relative. Acta Physiologiae Plantarum, v. 42, n. 2, p. 1-11, 2020. Available from: $<$ https://doi.org/10.1007/s11738-019-3005-8>. Accessed: Jul. 7, 2020.

MOURA, M. DE S. C. et al. The inclusion of spineless cactus in the diet of lambs increases fattening of the carcass. Meat Science, v. 160, p. 107975, 2020. Available from: < https://doi.org/10.1016/j. meatsci.2019.107975>. Acessed: Jul. 8, 2020. doi: 10.1016/j. meatsci.2019.107975.

NASSAR, R. et al. Modeling global atmospheric CO2 with improved emission inventories and $\mathrm{CO} 2$ production from the oxidation of other carbon species. Geoscientific Model Development, v. 3, n. 2, p. 689-716, 2010. Available from: $<$ https://doi.org/10.5194/gmd-3-689-2010>. Accessed: Jun. 5, 2020. doi: 10.5194/gmd-3-689-2010.

PARENTE, H. N. et al. Effect of the mineral fertilization on the initial growth and chemical and mineral composition of maniçoba (Manihot sp.). Revista Científica de Produção Animal, v. 9, n. 2, p. 102-110, 2007. Available from: <https://agris.fao.org/agris-search/ search.do?recordID=BR2008008796>. Accessed: May. 12, 2020.

SANTOS, K. C. et al. Nutritional potential of forage species found in Brazilian Semiarid region. Livestock Science, v. 195, n. November 2016, p. 118-124, 2017. Available from: <http://dx.doi. org/10.1016/j.livsci.2016.12.002> Accessed: Apr. 12, 2021.

SILVA, D. S. et al. Maniçoba hay in diets for sheep: Intake, apparent digestibility and nitrogen balance. Revista Brasileira de Zootecnia, v. 36, n. 5 SUPPL., p. 1685-1690, 2007. Available from: <https://doi. org/10.1590/S1516-35982007000700029>. Accessed: May. 8, 2020.

SILVA, K. B. Padrão Histo-Anatômico, degradabilidade e compostos secundários em acessos de Maniçoba. 2016. 54f. Dissertação (Mestrado em Zootecnia) - Programa de PósGraduação em Zootecnia, Universidade Federal da Paraíba.

SILVA, T. M. et al. Rumen degradability and nutritive value of wild cassava ensiled with levels of grape-wine residue. Archivos de Zootecnia, v. 60, n. 229, p. 93-103, 2011. Available from: $<$ http://dx.doi.org/10.4321/ S0004-05922011000100011>. Accessed: Oct. 22, 2020.

SOARES, J. G. G. Utilização e produção de forragem de maniçoba. Comunicado técnico da Embrapa Semiárido, p. 20-28, 1989. Available from: <https://www.embrapa.br/busca-de-publicacoes/-/ publicacao/133391/utilizacao-e-producao-de-forragem-demanicoba>. Acessed: Dec. 16, 2020.

SOARES, J. G. G. Avaliação da silagem de maniçoba - Teor de ácido cianídrico. Comunicado técnico da Embrapa Semiárido, v. 93, p. 1-3, 2000. Available from: <https:/www.embrapa.br/ busca-de-publicacoes/-/publicacao/134222/avaliacao-da-silagemde-manicoba---teor-de-acido-cianidrico>. Acessed: Dec. 16, 2020.

SOUZA, E. J. et al. Quality of wilted manioc (Manihot Epruinosa) silages. Archivos De Zootecnia, v. 55, n. 212, p. 351-360, 2006. Available from: <http://www.redalyc.org/articulo. oa? id=49521203>. Accessed: Jan. 9, 2020.

TARRASÓN, D. et al. Land degradation assessment through an ecosystem services lens: Integrating knowledge and methods in pastoral semi-arid systems. Journal of Arid Environments, v. 124 , p. 205-213, 2016. Available: <https://doi.org/10.1016/j. jaridenv.2015.08.002>. Acessed: Nov. 18, 2020.

VASCONCELOS, W. et al. Morphometry, production and chemical composition of Maniçoba and Pornunça as function of different fertilizer source. Revista Trópica: Ciências Agrárias e Biológicas, v. 4, n. 2, p. 36-44, 2010. Available from: <https:// scholar.google.com.br/scholar? start $=40 \& \mathrm{q}=$ morfometria $+\mathrm{ca}$ racterização+caprinos + nativos\&hl $=$ pt-BR\&as_sdt $=0,5 \&$ as_ ylo=2010\&as_yhi=2015\#6>. Acessed: Jul. 15, 2020. 